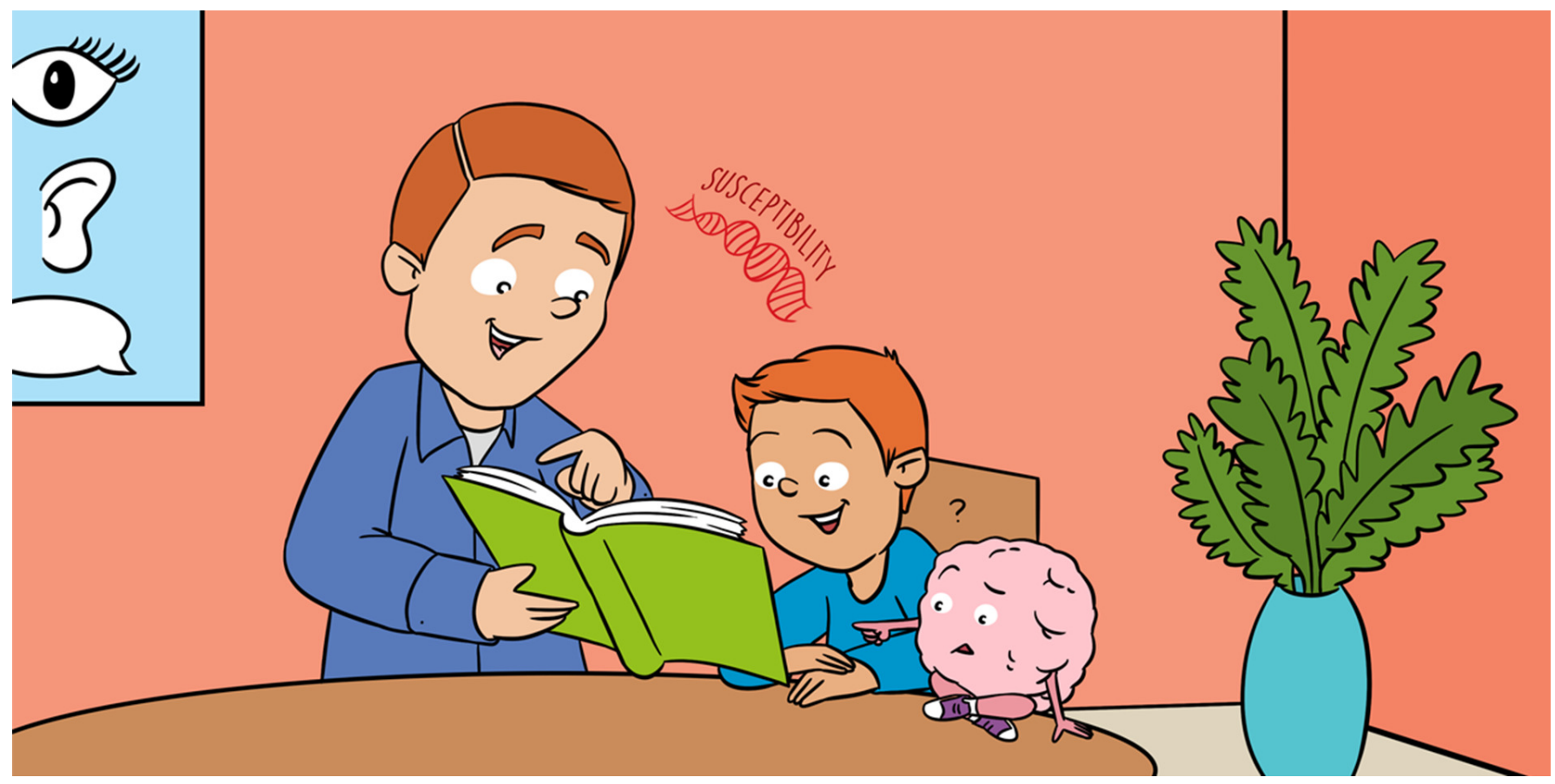

\title{
DEVELOPMENTAL DYSLEXIA: WHEN THE BRAIN STRUGGLES TO READ
}

\section{Gabrielle-Ann A. Torre ${ }^{1,2^{*}}$ and Cameron C. McKay ${ }^{1}$}

${ }^{1}$ Center for the Study of Learning, Department of Pediatrics, Georgetown University, Washington, DC, United States

${ }^{2}$ Communication Neuroscience Laboratory, Department of Speech, Language, and Hearing Sciences, Boston University, Boston, MA, United States

YOUNG REVIEWER:

GILI

AGE: 13
Developmental dyslexia is a learning difference in which people struggle with reading. Dyslexia is not due to low intelligence or the quality of classroom instruction. In fact, genes that play a role in language may impact people who have dyslexia. Brain imaging tools have also shown that the brain differs in individuals with dyslexia, and these differences in brain anatomy and brain function are in the parts of the brain that help us understand language. Children with dyslexia can improve their reading abilities with the right kinds of training, and these improvements can result in changes in the brain, too. There are still many things scientists are learning about the neuroscience of dyslexia. New discoveries could improve the lives of people who struggle with reading. 
DEVELOPMENTAL

\section{DYSLEXIA}

A learning difference that results in difficulties with reading

\section{SUSCEPTIBILITY}

\section{GENES}

Genetic information that makes someone more likely to develop certain traits.

\section{WHAT IS DYSLEXIA?}

Do you remember learning how to read? Probably not. Learning how to read is a normal part of childhood in most parts of the world, and this ability to view and understand written words plays a big role in learning new facts. Once we can read, it feels very natural to understand written words and say them out loud. Many of us may not realize what it would be like to have a hard time reading the many words that surround us: from books to signs, or even captions on TV.

About $5-12 \%$ of people have such a difficult time reading that it is considered a learning difference known as developmental dyslexia. People with dyslexia struggle with reading words quickly and correctly. They may also have a hard time spelling words or reading unfamiliar words out loud. These difficulties often impact a person's school grades and sometimes even their self-esteem. For a long time, many people assumed that people with dyslexia flip letters (like "b" and "d", or "p" and "q") or read words backwards (like "dog" and "god"). Another popular belief was that people with dyslexia are not very bright because they struggle to read. But these ideas are wrong! Dyslexia is not an issue of mixing up letters and words, and it is also not due to low intelligence, how many books one gets to read, or how well a school teaches reading. In fact, dyslexia has much more to do with genes, language, and the brain!

\section{WHAT CAUSES DYSLEXIA?}

So why do people have dyslexia? Years of research point to genes playing a big role. Genes are passed down to us from our parents and provide instructions for how our bodies work. Children are more likely to have dyslexia if they have a parent or older sibling with dyslexia. This led researchers to look for differences in genes related to language ability in dyslexia. Although there is not a single gene responsible for dyslexia, parents who have dyslexia are likely to pass down susceptibility genes to their children [1]. Susceptibility genes are instructions that make a child susceptible, or more likely, to develop a specific set of traits, such as having dyslexia. Currently, scientists think that there are several genes that might be involved in whether or not a person develops dyslexia, but that each gene plays its own small part in bigger picture [2].

Some scientists are interested in these susceptibility genes for dyslexia because they might affect boys and girls differently. Many studies show that boys are more likely than girls to have dyslexia. However, this fact is partially because most of the early experiments on the genetics of dyslexia only focused on boys and men. Today, scientists have begun comparing the genetics of both boys and girls with dyslexia. This step forward will allow us to understand whether susceptibility genes are the same or different for boys and girls with dyslexia. Research 
Figure 1

How does phonological decoding work to help us read words like "frontiers"? The different parts of brain that help us hear, see, and speak must work together speedily and fluidly to help us identify and read words.

\section{PHONOLOGICAL}

\section{DECODING}

The process of connecting the sounds of words with the written format.

MAGNETIC

RESONANCE

IMAGING

A method that scientists can use to take pictures of the brain.

\section{What is phonological decoding?}

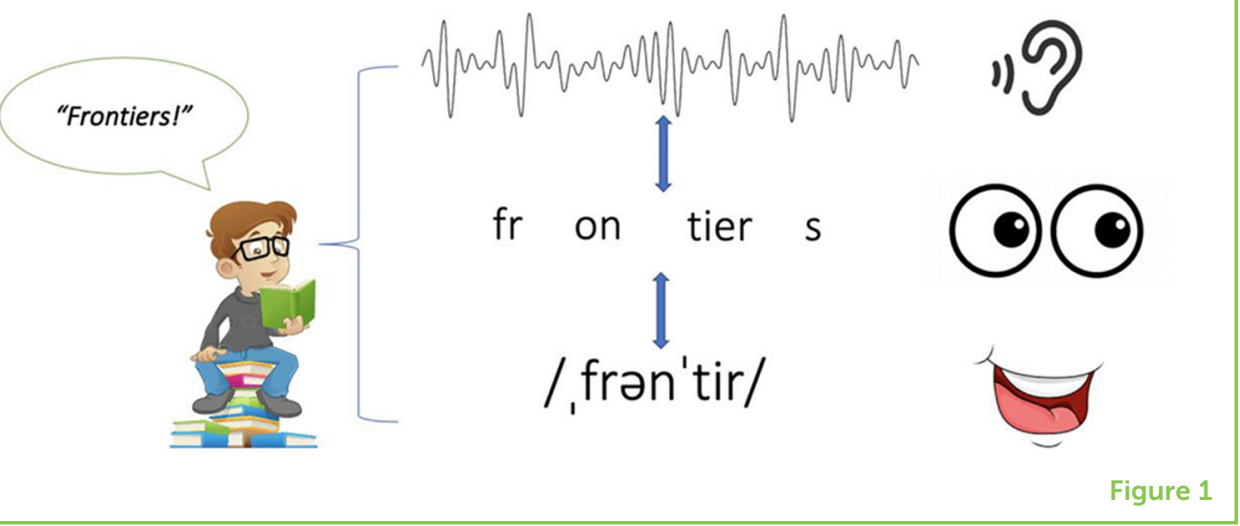

like this will also help explain why dyslexia is much more common in boys.

Another reason why most of these genes are interesting to scientists is because they are important for language. Language is a very important part of reading, since being a good reader also means being good at sounding out words. In fact, one of the major skills thought to be impaired in dyslexia is the ability to connect how words sound to how words look. This skill, called phonological decoding, is a language skill that helps us read words fluidly, like when a reader makes smooth and quick transitions between the sounds of words (Figure 1). Phonological decoding skills early in someone's childhood can generally be used to predict how good of a reader they will be. Scientists who look at dyslexia have focused on this skill and their work shows that phonological decoding is related to brain structure and brain function. Next, we will learn more about how the brain might be related to reading skills in dyslexia.

\section{DOES THE BRAIN LOOK DIFFERENT IN DYSLEXIA?}

Because the brain is the organ that helps us read, scientists have explored how and why the brains of people with dyslexia might be sized differently or even function differently from the brains of people who do not have trouble reading. One way that scientists have done this is to use a large, donut-shaped magnet to take pictures of people's brains using a method called magnetic resonance imaging, or MRI. Using this tool, scientists have found differences in the size of brain regions known to be involved in reading [3] and in the strength of the connections between those regions when comparing people who have dyslexia to people without reading problems.

Another way that scientists have studied brain differences is by testing how different parts of the brain function when people are 
Figure 2

Areas in green indicate regions of the brain that several studies have shown to be smaller in people with dyslexia [3]. Areas in blue show regions of the brain the show less brain activation during reading tasks in people with dyslexia [4].

\section{INTERVENTION}

A program or class designed to train specific skills, like phonological decoding.

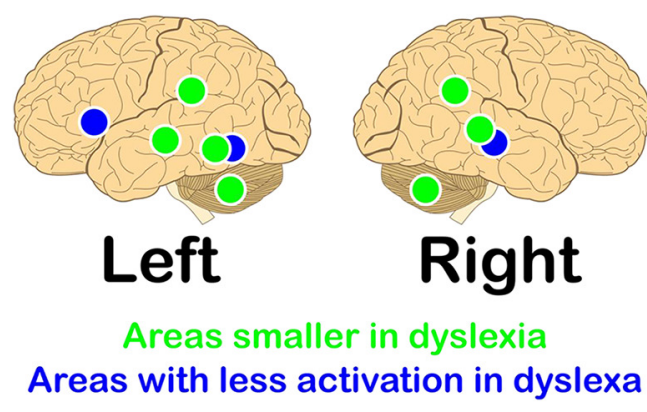

Figure 2

reading. Many studies show that the brain areas used for reading are different for people with dyslexia when compared to people without dyslexia (Figure 2). People with dyslexia have brains that show less activation in regions of the brain that help us understand language [4], and these may be the same regions affected by the genes we described above!

\section{HOW CAN KIDS WITH DYSLEXIA GET HELP?}

There are many ways that teachers, parents, and others can help children with dyslexia improve their reading abilities. The approach shown to consistently lead to improved reading in children with dyslexia is training focused on phonological decoding [5]. For example, teachers will help children with dyslexia, either in one-on-one or small group settings, to learn new steps to make sounding out words easier. This type of very focused training is also known as an intervention, because it involves a set of specific steps that will hopefully make academic skills like reading easier for children.

Scientists are testing whether these interventions lead to changes in brain function [6]. Many studies seem to show that after intervention in dyslexia, better reading skills come with increased activation in certain language regions of the brain-some of the very same regions we described above! This might mean that, when reading improves in people with dyslexia, the areas of the brain affected in this disorder work more like the brain areas of people without dyslexia. Some studies also show that certain brain areas also increase in size, which may reflect the use of new skills applied while reading. This is exciting new knowledge that helps us understand that students with dyslexia use a large mix of brain and behavior strategies to achieve successful reading skills!

There is still much to learn about the science of dyslexia. As more is known about the behavioral, genetic, and brain causes of dyslexia, more can be done to improve the lives of children and adults who struggle to read. 


\section{REFERENCES}

1. Carrion-Castillo, A., Franke, B., and Fisher, S. E. 2013. Molecular genetics of dyslexia: an overview. Dyslexia 19:214-40. doi: 10.1002/dys.1464

2. Peterson, R. L., and Pennington, B. F. 2012. Developmental dyslexia. Lancet 379:1997-2007. doi: 10.1016/S0140-6736(12)60198-6

3. Linkersdörfer, J., Lonnemann, J., Lindberg, S., Hasselhorn, M., and Fiebach, C. J. 2012. Grey matter alterations co-localize with functional abnormalities in developmental dyslexia: an ALE meta-analysis. PLOS ONE 7:e43122. doi: 10.13 71/journal.pone.0043122

4. Hancock, R., Richlan, F., and Hoeft, F. 2017. Possible roles for fronto-striatal circuits in reading disorder. Neurosci. Biobehav. Rev. 72:243-60. doi: 10.10 16/j.neubiorev.2016.10.025

5. Scammacca, N. K., Roberts, G., Vaughn, S., and Stuebing, K. K. 2015. A meta-analysis of interventions for struggling readers in grades 4-12: 1980-2011. J. Learn. Disabil. 48:369-90. doi: 10.1177/0022219413504995

6. Barquero, L. A., Davis, N., and Cutting, L. E. 2014. Neuroimaging of reading intervention: a systematic review and activation likelihood estimate meta-analysis. PLOS ONE 9:e83668. doi: 10.1371/journal.pone.0083668

SUBMITTED: 26 February 2020; ACCEPTED: 17 August 2020; PUBLISHED ONLINE: 23 September 2020.

EDITED BY: Caroline A. Niziolek, University of Wisconsin-Madison, United States

CITATION: Torre G-AA and McKay CC (2020) Developmental Dyslexia: When the Brain Struggles to Read. Front. Young Minds 8:538176. doi: 10.3389/frym. 2020.538176

CONFLICT OF INTEREST: The authors declare that the research was conducted in the absence of any commercial or financial relationships that could be construed as a potential conflict of interest.

COPYRIGHT @ 2020 Torre and McKay. This is an open-access article distributed under the terms of the Creative Commons Attribution License (CC BY). The use, distribution or reproduction in other forums is permitted, provided the original author(s) and the copyright owner(s) are credited and that the original publication in this journal is cited, in accordance with accepted academic practice. No use, distribution or reproduction is permitted which does not comply with these terms.

\section{YOUNG REVIEWER}

\section{GILI, AGE: 13}

Hi, I am Gili. I am in seventh grade. I am very interested in science and math. I like reading, playing the violin and piano, hiking with my family, and doing sports like ball games and running. 


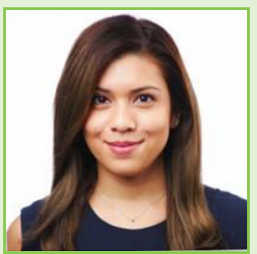

\section{AUTHORS}

\section{GABRIELLE-ANN A. TORRE}

Gabrielle-Ann Torre is a Post-doctoral Fellow in the Department of Speech, Language, and Hearing Sciences at Boston University. Her research focuses on using brain imaging methods to understand how the brain's function and anatomy support reading abilities, as well as other forms of classroom learning and communication. *gat@bu.edu

\section{CAMERON C. MCKAY}

Cameron McKay is a Ph.D. Candidate in the Interdisciplinary Program in Neuroscience at Georgetown University. He uses brain imaging to study how differences in academic abilities, such as reading and math are related to brain structure. In addition to his research, Cameron is passionate about science communication and outreach. 